Mid-American Review of Sociology

Hindelang, Michael J.

1976 Criminal Victimization in Eight American Cities: A Descriptive Analysis of Common Theft and Assault. Cambridge: Ballinger.

McIntyre, Jennie

1967 "Public Attitudes Toward Crime and Law Enforcement," The Nunnally, Jim Annals 374 (November):34-46.

1967 Psychometric Theory. New York: McGraw-Hill

President's Commission on Law Enforcement and Administration of Justice, Task Force on Assessment

1967 "Crime and Its Impact-An Assessment," Washington, D.C.: U.S. Government Printing Office.

Reiss, Albert J., Jr.

1967 "Public Perceptions and Recollections About Crime, Law Enforcement, and Criminal Justice." In the President's Commission on Law Enforcement and Administration of Justice: "Studies in Crime and Law Enforcement in Major Metropolitan Areas," 1(2), Field Surveys III. Washington, D.C.: U.S. Government Printing Office.

Reppetto, Thomas A.

1974 Residential Crime. Cambridge: Ballinger.

Roper Public Opinion Research Center

1975 Current Opinion 3 (September):84-85.

U.S. Department of Justice, Law Enforcement Assistance Administration

1974 Crimes and Victims: A Report on the Dayton-San Jose Pilot Survey of Victimization. Washington, D.C.: National Criminal Justice Information and Statistics Service.

\section{THE IMPORTANCE OF SYMBOLIC AND CULTURAL POLITICS IN THE \\ MARCUS GARVEY MOVEMENT}

\author{
Dr. Doug Gutknech \\ Chapman College
}

Mid-American Review of Sociology, 1982, Vol. VII, No. 1:87-107

This research incorporates interdisciplinary data in order to discuss the Marcus Garvey Movement which emerged in the urban North during the World War I era. The importance of symbolic and cultural politics for Garvey's appeal to newly arriving, often uneducated and unskilled northern urban Blacks, is elaborated. Such forms of symbolic communication and politics, along with Garvey's inability to anticipate repression and other macro-structural issues and conditions, created intense conflicts with potential allies, as well as his own followers. Garvey's form of ideological or symbolic politics provided short run successes in the recruitment of poor, relatively uneducated segments of the Harlem community to his racial struggle. However, in the long run, Garvey failed to provide leadership and tactical direction for a sustained broad based movement for racial equality.

This research will articulate the symbolic politics of Marcus Garvey's Universal Negro Improvement Association (U.N.I.A.) movement which emerged in the urban North during the W.W. I era. I will introduce an interdisciplinary perspective in order to provide a more comprehensive understanding of historical data about Garvey. This research utilizes cultural categories like symbolism, ideology, and ritual to complement traditional political and historical data.

Garvey's political movement may be identified as a form of emerging urban nationalism; its historical thrust emerged from general historical and social conditions prevalent at the end of the 19th and the beginning of the 20 th century in the urban northeast. Garvey's ideas became part of a historical dialogue 
with these social conditions; conditions which help account for the political and cultural tone of Garvey's attempt to rally the migrating urban Blacks. However, the unique form Garvey's ideas took resulted from his cultural sensitivities to the migrating Black masses who responded to Garvey's symbolic and ritualistic type of politics. Such cultural sensitivities actually undermined Garvey's ability to create a long-term viable political movement for racial justice in the northeast during this period.

This research is divided into several sections: First, a brief discussion of the basic frame or analysis, cultural, and symbolic politics; second, I will outline the general macro-social, economic, and political conditions existing during the early 20th century which Garvey and other Black leaders had to face and respond to within their respective ideological programs; and third, a discussion of Marcus Garvey's Jamaica background will provide clues as to why Garvey opted for the type of cultural and symbolic form of politics, yielding outstanding short run successes and failures in the long run.

The significant facts of ethnic history emerge most often as the meander of mundane events and people, caught in larger circumstances; those required to act in their own interest often fail. Simple fits, starts and failures, not just cataclysmic transformations, must gain documentation by those interested in a more complete historical record. Such attention is particularly warranted when discussing the historical record of urban racial movements during the W.W. I era. Analysis and interpretation must not ignore forms of communication available to those cut off from mainstream cultural resources including traditional literacy and communication technologies.

Many historians seemed preoccupied with the monumental historical events. Not surprisingly historical preoccupation with major stages of history and political events often ignore those groups and leaders unable to significantly alter the structure of society. Although underrepresented in the historical record, these submerged events often point to important issues which require analysis and discussion. Likewise sociologists of knowledge have often overemphasized the importance of major macrosocial structures and ideologies regarding feudalism, socialism, capitalism, and mercantilism. Thus, certain biases intrude into the social sciences when examining the relationship of political ideas and conditions influencing their emergence (Kuklick, 1980:5-21; Aronowitz, 1979:125-148). Major ideas and political ideologies often gain ascendency in the historical record, while the minor political and cultural struggles, over ideas and practices, remain unexplored. Treatments of major political events and historical junctures often hide changes in the cultural conditions of the lives of the submerged, marginal members of society and the existence of unique leaders who speak to these peoples' needs. Of course, where one level of analysis may provide a perfect explanatory framework for historical facts, in the short run, ignorance of less sweeping conditions, questions, issues or ideas may ultimately jeopardize a more comprehensive picture in the long run. At the same time, a narrow empiricism may error in the opposite direction. The larger analytical task requires a perspective that considers both larger social conditions and the daily political life or mundane cultural conditions of marginal societal members: the link between them requires analytic pause and reflection.

Such a view requires recognition of the relationship between larger macro-political, economic, social, and cultural conditions displayed in the mediations of daily concrete struggles (Berger, 1981:170). Thus, any study of social and political movements, divorced from the field of cultural forces, often downplays the role of symbolism and its essential purpose: the integration of dispersed ideas, actions, trends, opportunities, organizational tactics and strategies into a meaningful pattern capable of energizing followers. The emergence of Black nationalism in the urban North during the W.W. I era is one example of both a social and symbolic movement. One form of symbolism is ideology. Alvin Gouldner (1976:250) defines the roots of ideology as a moral and integrative undertaking; the integration of fragmented beliefs and actions in order to guide the creation of human solidarity, joint action, and the attainment of a new vision. Such a view highlights positive cultural dimensions of ideology in contrast to the predominantly negative view which reduces ideology to reified rationalizations of 
material class interests. Ideological-cultural mediations may serve both purposes: intensifying class conflicts and emphasizing differences, including racial ones, by masking subtle and unimportant differences and creating the possibilities for joint action, shared suffering, and long run commitment.

Another important component of symbolism is ritual. Several recent social scientists (Edelman, 1966; Klapp, 1964; Gusfield, 1966; Combs, 1980) have written of the symbolic and ritual functions of politics. Ritual and symbolic appeals provide a dramatic connection between the political-instrumental and culturally-expressive realms when political groups use and manipulate potent symbols during ceremonials, memorials, parades, meetings, festivals, inaugurations, elections, etc. Charismatic political leaders often guide their followers by emphasizing ritual politics which celebrate and affirm important values and beliefs. In fact much political and instrumental action is ritualistically designed to assure the masses, appeal to their common suffering and oppression, celebrate old traditions, alliances, and revive the belief in the possibility of a newer, better world:

Political ritual is something of a reminder. It focuses attention on reified political definitions, and re-asserts, even magically reinvigorates the symbols we believe in, but rarely talk about. At its most abstract level, ritual evokes myth: unquestioned and deep beliefs about the origin, structure and destiny of a people. It relates the communicants at a ritual to the 'symbolic umbrella' of the cultural order, political rituals evoke the political myths of culture, infusing the rite with symbolic meaning and magical properties (Combs, 1980:23).

Thus, political activities often have less to do with changing the world and more to do with dreams, myths, ideologies, and solidarity building. Such symbolic elements communicate historically important memories in dramatic displays of harmony and consensus. The formalized and stylized simplicity of expression in such symbolic forms permits ready emotional identification and support for the political and cultural myths that must be sustained. Such social-cultural-political dramas may reaffirm personal identity and loyalty to group life and provide a ready symbolic vehicle for the assertion of new rituals, ideologies, myths, and ceremonies related to the past. Here one can see the enormous potential political gain available to those capable of using symbolic manipulation in ritual, ceremony, and other cultural modes to further political programs.

Symbolic politics, ritual activities, myth and ideology serve as devices for storing and transmitting meaning in a very special way. Diverse symbols may be ritually displayed and repeated in various contexts, giving them what one communication theorist (Klapp, 1978:108-134) has called a "high redundancy" factor. Thus, a link between the celebration of cultural identity and potential for political manipulation.

Historical inputs, such as conflicts and the deeds of heroes, nourish collective memory and pride. Ritual recalls and intensifies such images and feelings of togetherness (Klapp, 1978:15).

Ritual is a mechanism for symbolic and cultural manipulation which like ideology has both a positive and negative side. The positive side is feedback. Ritual here functions as a mechanism for sustaining positive redundancy: the relationship or bond between personal identity and cultural-historical tradition is reinforced by repeating positive historical moments and forgetting the weak, negative, trivial, or divisive. The negative mode ritual sometimes masks conflicts or interest and real differences while eulogizing the mythic past, and ignoring real historical mistakes and failures.

Ritual, myth, and symbols enlarge the discussion of instrumental-political action to include the important expressive dimensions. Cultural rituals allow political and social movement organizations to rationalize collective distress, resource problems, and social conflicts, at a level where intense and unpredictable emotions may be displayed and even channeled into stylized conventionalized and safe expression: 
Political rituals are drama.... They are a dramatic play in which a group ritually enacts its belief in its legitimate power: e.g., its internal cohesion, its differentiation from the rest of the world, its right to visit retribution (Klapp, 1978:12).

E. Kahler (1970) provides a conceptual link to enable one to move from one level of analysis to another: the concept of symbol. The symbol becomes a conceptual or cultural "briding act" which mediates or connects different levels and domains of experience. The most concrete level includes behavioral moving through successive levels of generality to include groups, organizations, and culture. The most abstract level provides the umbrella of symbolic ties reflected in linguistic forms. Such symbols become rooted in rituals, customs, and ideologies of groups as previously developed historical legacies become available for use in the mobilization of new members to accomplish agreed upon goals. Symbols may thus have extremely narrow referents, as in single words or signs, or involve multiple and potent meanings, as in social movement or organizational ritual, ceremonies, folklore, or mythic stories. Such symbols compress many intense historical memories, emotions, and thoughts into unified and passionate displays of unity and sharing.

Symbolic behavior like rituals seem to appear most consistently at those moments of crisis in human affairs: birth, deatk, war, struggle over meaning; and transitions in individuals; groups and organizations. Uncertainty and times of turbulence often create stress and overload for those individuals not integrated into dominant support systems: Those individuals at the margins of society and group life. Symbolic activities including ritual politics which becomes part of a total community way of life, may stabilize self or allow alternative identities to emerge. These identities are sustained by repetitive statements of custom and tradition regarding where one has been, who one is, and where one is going. Klapp (1978:39-40) suggests that culturally indigenous symbols function to reestablish group boundaries and yield consensus of meaning and purpose:
Arising naturally and used in a local group, rich in meaning maintained by interpersonal networks, support status, collective identity and sense of place....

Social movements and organizations often utilize cultural and symbolic resources; particularly when material and technological resources are lacking. The need for recognizing such dimensions of social movement culture is compatible with the belief that movements are both constrained and active participants to their own internal and external struggles over power, resources ideological hegemony, and the allegiance of potential recruits. The cultural choices a social movement offers its members provide a symbolic framework or style for political and social interaction both within the organizational structure and with external groups. Culture becomes a resource allowing creativity and reflexivity embodied in symbolic styles of appeal to members, as well as a constraint which shapes, molds, and patterns those options and opportunities for decision making.

Rarely does the question of symbolic politics achieve such a pivotal position as during the period of the emerging 20th century in America's rapidly urbanizing Northern cities. The period 1900-1925 provides the most dramatic test for the meaning of a radical Black segregationist cultural appeal in the midst of dominant assimilationist ideologies of both middle class intellectual reformers and Blue Collar urban ethnics (Dubois, 1913:45) Given the existence of a dominant Anglo-Saxon core culture (Gordon, 1964:72, 74) and the institutional structures that articulated these core values in social practice, the question of assimilation and segregation took on significant potential cultural and symbolic overtones. The lack of indigenous cultural support systems created a situation where symbolic politics replaced rather than supplemented autonomous political activities.

Harold Cruse (1967:134) poses the question of Black oppression in cultural terms:

The Black intellectual artistic class, best suited to articulate the political concerns of the Black people, never receives support 
or resources from the dominant Anglo, artistic or political establishment cultural identity, essential for the assertion of political responsibilities, never developed independent of outside penetration.

C. Lasch (1974:190-200) views the issue as more than artistic colonialization; it implicity includes cultural, political, and economic penetration of the urban ghetto, like Harlem in the 1920 s, causing collapse of not only the Black artistic colony but the vulnerability of urban Blacks to dramaturgical and symbolic strategies. In Lasch's wider scenario disorganization, insecurity, and fear created by such total, external penetration of the ghetto colony escalated the potential internal exploitation (Blauner, 1972; Tabb, 1970:21-34; Fusfeld, 1973:4-15). Such social cultural penetration indicating powerlessness on the part of the Black community, allowed a potential opening for alternative political or cultural appeals by groups who spoke the language of the oppressed masses. Lasch (1974:196) summarizes the modern results of the interrelationship of political and cultural exploitation in the following way:

Those who deny the pathological elements of the culture of poverty would do well to ponder Malcolm's account on his own degradation, in a world where high status meant light skin, straight hair, the company of white women, and flashy clothes manufactured by while merchants especially for the ghetto and sold at inflated prices....

The pre-W.W. I period provided the culmination and dramatic contest for the meaning of several important historical events: the failure of reconstruction, the emergence of Jim Crow segregation in the urban South, the loss of romantic illusions and deflation of the Northern urban rhetoric that racism had been eradicated (Drake, 1932). Such events urgently underscored the weakened self-esteem that many rural Blacks brought to the crucible of the Northern urban ghetto. The necessity for some form of personal and social identity and solidarity in the face of destructive urban forces became evident to some Black leaders, particularly those sensitive to racial humiliation and aware of nationalistic symbolism. Nationalists, like Marcus Garvey, articulated a form of cultural support system that had its roots in rural Southern culture but which needed more vigorous elaboration to meet the changing circumstances of urban ghetto life. Garvey's brand of nationalism built upon symbolic identification with themes of oppression which linked personal identity with collective group struggles. Such a movement built upon the discontent of the illiterate newly arriving Blacks who found it difficult to trust a distant better world offered by more sophisticated and intellectual middle class Blacks. Let me briefly outline the conditions leading to the situation in the urban North.

After the Civil War, Southern Blacks gradually developed reworked cultural patterns and responses to the break up of slave plantations. Although the South had not generally been considered an optimal climate for nourishing the conditions necessary for nationalistic assertion (Redkey, 1974:360) a mass based Southern did emerge in the 1890s. Harvey NcNeal Turner appealed to Black sharecroppers and rural workers who had begun to see the dreams of the Reconstruction era recede, replaced by the lynchings, humiliation and the new forms of Jim Crow institutionalized racism (Wilson, 1973). Disenchantment, violence, and repression became extreme in the late $1880 \mathrm{~s}$ and early 1890s in the South. The desertion of the Northern elites, after Reconstruction, combined with early industrialization of Southern agriculture and the break up of the Populist coalition, enhanced this despair. One might also observe that both decades of the 1880s and the 1890s were times of intense worldwide nationalism (Redkey, 1974:400; Wilson, 1973:93119; Stampp, 1965).

Bishop Turner's nationalism appealed to racial pride and dignity but found few resources to build a movement in the rural South (Pinkey et al., 1976:29-36). His "home to" theme, delivered from the pulpit of the African Methodist Episcopal Church, appealed to the real needs of rural Blacks (Pinkey et al., 1976:28). Turner could not tap a consistent resource base to build an organization. In any case a critical mass of 
people needed to build a movement did not exist. Claude Fisher $(1976: 27,35-38,67,97)$ in his subcultural theory of urbanism suggests that both a critical mass and forms of eary communication are essential for the creation of urban ethnic subcultures. Rather than suffer political and social isolation, oppression, Black lynchings and mass disenfranchisement, rural Blacks migrated North.

The vast migration of Blacks to Northern cities became massive after 1915 and occurred in key Northern industrial cities like Pennsylvania, Illinois, Ohio, New York, and Michigan (Klebanow et al., 1977:298-313). Decade totals suggest an even greater growth during the 1920s; for the decade of 1910-1920, 454,000 people; the decade 1920-1930, 747,000 people (Twombly, 1971:165). The emergence of World War I, dramatically altered the employment situation in the urban North, as war time industrial recruiters actually traveled South to spread the word of unlimited opportunities by offering free transportation (Twombly, 1971:172). The war itself drastically reduced the influx of European immigrants, dropping the totals from a 1911 high of 1.3 million to a 1918 low of 110 thousand (Spear, 1967:131). Personal letters and Black newspapers, like the Chicago Defender, spotlighted Southern brutality and violence, while praising city employment opportunities and political freedom (Spear, 1967:134).

Thus, one can see both push and pull factors leading migration. The push factors involved: racism, separate facilities, diminishing returns from cotton farming, share cropping, lynchings, disenfranchisement, and limited ability to use the political process to protest one's rights. The pull factors included: romantic idealizations of the North as free of racism, the valid recognition that wages were higher, political gains accruing to Blacks via patronage, and the protection of concentrated numbers.

Problems, however, were immediately apparent to Black leaders in Northern urban communities. The protection of large racially homogeneous communities brought ghettorization, rent gouging, slum lords, overcrowding, health problems, etc. Twombly, 1971; Franklin, 1974:354-361; Lacy, 1972:143-144).
Bonachich documents a split labor market where Blacks were paid less for the same work, worked longer hours, held less pretigious and lower status jobs, and were kept out of unions, manipulated by capitalists as strikebreakers, discriminated against by White unions, and displaced by automation (Bonacich, 1976:34-51; Meier and Rudwick, 1970:192-200).

The great migration of Blacks intensified opportunities for creative interchange, as in the Harlem Rennaissance, which attracted the talented like a magnet; yet, it also left Blacks vulnerable to exploitation. The existence of concentrated numbers of urban Blacks often became a two-edge sword, capable of responding to political appeals, yet, susceptible to cultural and symbolic manipulation. The question became who could best articulate a program to deal with the ambivalent and vulnerable situation of oppressed, urban Blacks.

The concept of symbolism inherent in culture provides an important link for understanding the appeal of men like Marcus Garvey to the newly segregated, poorly educated, exploited Blacks. Such supporters responed to the symbolically uplifting appeals for personal assertion and group solidarity. Such appeals should not be impugned as either invalid or expedient but in the interests of many Blacks lacking the resources, education, or sponsorship to build adequate urban based subcultural worlds (Yinger, 1960:625-635). Blacks needed options because the context of upward mobility changed: integrationist and coalition based, patronage politics of earlier European ethics proved less than reliable. Symbolic politics became the cultural focus of Garvey's movement expressed in a new symbolic and emotional style. Such a style although emphasizing many traditional political concerns of importance to the Black community, alienated many traditional segments of the Black community including middle class intellectuals and artists.

Marcus Garvey, stepped into this volatile climate of the Harlem ghetto during the critical, historical World War I juncture. Although arriving in the United States in 1916, the Garvey movement, organized as the Universal Negro Improvement Association (U.N.I.A.) expanded greatly after W.W. I's end. Several factors account for the sudden rise: the return of Black 
soldiers to post-war industrial unemployment, slum housing conditions, a reemerging Southern urban Ku Klux Klan, and urban ghetto riots (Pinkney, 1976:37-40). Harlem was an appropriate urban center stage for Garvey to orchestrate his ideological system and mobilize the masses.

Garvey's strengths and limitations resulted from his strong use of oral and ritual traditions that struck a resonant cord with the migrating lower class Blacks who possessed little formal literacy and education (Nelson, 1976:51). After all, rural Blacks long thrived on creating folk forms of media and communication and a culture of resistance. LeVine takes to task historians studying the Urban migrants of the early 20 th century for ignoring the transfer of styles of Black cultural protest and cultural resistance:

On the whole, such discussions have ignored the evidence of Black folklore, Black music, and Black humor with their array of such heroes and models as tricksters, bad men, blues men and the evidence of lower class Black culture in which entertainers, preachers, and underworld hustlers often occupy central position (LeVine, 1972:135).

Entering the Harlem scene with a rush, and theatrical flair at this historical moment, allowed Garvey to encapulsate and summarize the salinet symbolic themes of these submerged urban Blacks by utilizing this oral and ritualistic tradition. Likewise, Bed Sindran (1971) suggests that the importance of music for Black culture relates to its fundamental orality and the relation of Black music to this oral tradition. Sindran equates such orality with the ability to improvise, as is often seen in urban Black jazz and blues musicians and possibly one reason these cultural interpreters have often been considered a vanguard for Black culture. One indicator of the inability of middle class Black urban political leaders and urban cultural intellectuals to speak the language of the masses, is revealed by Nathan Huggins in his comment on the Harlem Rennaissance:
Harlem intellectuals promoted Negro art, but one thing is very curious, except for Langston Hughes, none of them took jazz-the new music-seriously. All said it was important in the definition of the New Negro. But none thought enough about it to try and figure out what was happening. They tended to view it as a folk art-like the spirituals and the dance-the unrefined source for the new art (Huggins, 1977:9-10).

Thus, one may view the interest of many urban Blacks in jazz and Blues musical idioms as a form of oral and improvisional communication which seemed to resonate with a newly arrived, relatively uneducated urban Black population. Black leaders and organizations did develop their own newspapers and literacy forms appealing to artists and middle class intellectuals (Cruse, 1967:11-63, 420-475; The Crisis [NAACP]; Opportunity [National Urban League]; the Messenger [A. Philip Randolph]; and Negro World [U.N.I.A.]). However, Garvey did not depend on graphic, written tabloids alone; oral communication and ritual involvement proved more effective for Garvey's Black populist appeal. However, unlike the Harlem Renaissance, which Claude McKay felt was kept alive by white Bohemians (Huggins, 1977), Garvey's movement had indigenous roots beyond the realm of outside forces.

Garvey's brand of symbolic and ritualistic politics appealed to "both protest and fellowship" (Clarke, 1974:XXIX). Garvey asked, "Where is the Black man's government? Where is his King and Kingdom? Where is his President, his country, his ambassadors, his Army, his Navy, his men of affairs" (Clarke, 1974:8)? Adopting a mixture of Catholic and Christian ritual, African tribal lore and official pageantry and titles Garvey taught his people to dream of an emerging great race. Chronon (1955) appropriately titles his work "Black Moses," for Garvey addressed the oppressive conditions and emerging cynicism of the postwar era with a religious fervor resembling Moses appeal to the children to Israel. Franklin Frazier notes practical, ritualistic and utopian elements in Garvey's mass-based style: 
He not only promised the despised Negro a paradise on earth, but he made the Negro an important person in his immediate environment. He invented honors and social distinctions and converted every social invention to his use in his effort to make his followers feel important. While everyone was not a 'knight or sir': all his followers were fellow-men of the Negro race.... The women were organized into Black Cross Nurses and the men became uniformed members of the vanguard of the great African Army. A uniformed member of a Negro lodge paled in significance beside a soldier of the Army of Africa (Clarke, 1974:238)

Followers overflowed his 6,000 seat liberty hut tabernacle every Sunday evening, and one evening in 1921, he crowned himself president-general of the U.N.I.A. and provisional president of Africa.

Marcus Garvey's program blended a unique mixture of cultural and political themes. His cultural message not surprisingly, was most convincing to his followers when it ignored intellectual complexities, political, and class realities while focusing on concrete issues like self-reliance and economic self-help in a symbolically potent way. Garvey is political and his cultural program resembled Booker T. Washington's economic program of building indigenous economic institutions in order to create a self-sustaining community (Clarke, 1974:6). Garvey exhorted his followers to embrace his program, join the U.N.I.A. buy stock in the Black Star Steamship Line, participate in their religious ceremonies, pagentry and cultural activities, and have faith that the dreams of freedom in a new land would come true. However, the political realities of groups competing for the allegiance of the Black community required more rigorous analysis, and constant adjustment of strategy. Garvey's emphasis on the subleties of the color line prevented him from constructing a more comprehensive political agenda (Martin, 1974:436).

Garvey's biographical background in Jamaica yields some possible clues about both his successes and failures: his success in mobilizing poorer Blacks and failure in providing a viable alternative for more educated, intellectual, and culturally radical middle class Blacks. Garvey's failures cannot be reduced to only psychological causes or explanations. However, the relationship of the personal, cultural symbolic, and the political has received more attention as a result of dramaturgical theory (Edelman, 1966), symbolic interactionists (Klapp, 1964:78), ecletic sociological theorists (Goffman, 1959; Gusfeld, 1966), and cultural critics (Lasch, 1974:79; Berger, 1981). For example, Christopher Lasch (1979) views the social conditions and institutional structure of an industrial, consumption orientated, bureaucratic society as influencing the development of a typical personality configuration called narcissism. In this view institutions support and reinforce such narcissitic traits as the escape into hedonism and privatism. Such and intriguing analysis applied to leaders of the violent radical left and right yields numerous insights, regarding the direction their movements take; as well as provides a portrait of traits displayed by leaders and followers (i.e., impulse ridden, shallowness of involvement, lack of reasonable guilt, fear of dependency and commitment, rage, feeling of moral deprivation, and megalomania). Calling attention to the types of early socialization experiences resulting from different institutional contexts may yield much useful information regarding political styles and involvements.

Like Brazil, Jamaica developed a distinction during the slave era, between a Black and a mixed, mulatto class. Although race consciousness existed, the distinctions of color became muted when opportunities for class mobility arose. Color awareness provided a subtle reminder of class and vice-versa but racist ideologies, justifying the system of exploitation were less needed in a system not relying on democratic ideology (Mason, 1970:17-18; Davis, 1966). In this system race became a classbased attribute, capable of being transcended at the appropriate time, not the cause of an ideology of racial inferiority.

Blacks at the bottom of the status system developed an awareness that light skin often meant enhanced status. Lower status dark-skinned Blacks could always hope to improve their fortunes in the future. Middle status mulattos viewed their desirable priviledged position by comparing themselves with unfavorably placed lower status Blacks; often undercutting 
any possible alliance based on the awareness racial exploitation. The dominant class supported such divided and conquered strategy by emphasizing the lack of racial discrimination. The mulattos, unlike the Coloreds in South Africa are not a permanent group. Mulattos may aspire to upper status through occupation, education, family ties, etc. The mulattos absorb darker-skinned Blacks, while themselves becoming absorbed by lighter skin dominants.

The paradoxical effect of viewing color as a criterion of social rank as in Jamaica and Brazil is that it intensifies color awareness particularly for those migrants entering societies where a more rigid racial stratification system exists. In such a context where color is a mere limitation not an absolute obstacle to mobility, one may also find a sense of rising expectations and aspirations. Although one may indeed argue that such a situation has existed in the U.S. since the 1960 s, one cannot deny the excessively constricted conditions of urban ghetto life during the 1920s. The important point here is not to build a simplistic model of political socialization but to recognize one powerful early background influence on Garvey's latter political style in a cultural context ripe for change.

The fundamental appeal of Garvey was to people existing with the social and cultural wastelands of the inner-city ghetto. Although Black leaders like Dubois consistently criticized Gravey for his narrowness, chavinism, and demogogic qualities, Garvey's appeal was immense (Vincent, 1970; Fox et al., 1972). However, his symbolic and cultural appeals often took precedence over the need to create a wider base, beyond the confines of the ghetto. One must be careful not to place all the blame on Garvey as the failure to create political alliances in the Black community also resulted from rigidity and inflexibility on the part of more middle class Blacks and other intellectuals.

Martin (1974:434) believes the essential struggle Garvey faced was one of class. Garvey gave this class struggle a large dose of color. Garvey did not create these facts, but merely tried to radicalize an ambiguous situation to his advantage. Garvey used the elitism inherent in the ideas of the "talented tenth" and the "blue view society" to preach against trends that might amplify an autocarcy of light skin; something already established by 1920 . Garvey's sensitivity to other middle class Black intellectuals has its roots in part, from his earliest socialization in Jamaica. Garvey tried to generalize themes of injured identity to larger racial issues. The consequences of relying on symbolic forms or building racial pride and self-reliance created a limited conception of political realities and a distorted view of social class within the Black community (Nelson, 1976:61). Garvey's militant racial rhetoric provided gains in the short run, while ignoring the necessity of building viable political programs for the long run.

One line of reasoning might explain Garvey's failure to build adequate alliances or coalitions: the failure to fully understand the state of political and cultural confusion during the 1920s in newly emerging Black urban ghettos like Harlem. David Nelson summarizes the complexities of this situation:

The political distinction between the radicals and the old crowd Negroes reflected a power fight which found on the one hand, nationalists, socialists, Communists, trying to build a new basis of power in the urban community; and on the other hand, the combined forces of the NAACP and the other Civil Right groups, plus the old line approach of the late Booker T. Washington (Nelson, 1976:69).

Thus, Garvey's symbolic appeals took on a puritanical racial tone in changed circumstances where opportunities for class or group mobility were denied. The class question thus became in the urban North, submerged to a symbolic and cultural one. The difficult task for Garvey was the creation of a racial protest culture in order to strategically confront the exclusion and institutionalized forms of racial oppression in the urban North. Garvey's emphasis on cultural and symbolic themes had less appeal to middle class professional Blacks who had some vested interest in dominant institutions and at least the opportunity, in theory, of mobility. Garvey rather than trying to create a movement based on traditional class politics, believed cultural and racial questions were primary: the struggle for mobility 
and opportunity to compete rested on a viable set of cultural institutions, and race self-pride. Garvey's symbolic style of politics often alienated him from those possessing resources, political contacts, formal means of disseminating information, etc.

One facet of this research which greatly interests me in this time of general political apathy particularly among the poorest and most defeated in our midst, is Garvey's ability to temporarily organize an effective movement of people one would not expect could be mobilized. Most often he achieved his effect by recognizing the usefulness of symbolic and cultural modes of politics especially for those caught between two informational and cultural worlds such as, traditional rural and modern urban. This oppressed group responded to Garvey's orchestrated images which transcended drab politics. Garvey cannot be accused of falling prey to what Lionel Trilling has called the "liberal imagination": the emphasis on non-political, psychological elements of individual lives, divorced from group solidarity and community action. However, Garvey failed to resolve the tensions within his own program and style of presentation by transcending his own propensity to engage in symbolic manipulation of complex issues.

In the final analysis Garvey's movement proved unable to develop reflectivity about its own identity and direction, to examine the larger picture of common oppression facing Blacks of all skin tone, as well as other minority groups, labor, and other cultural intellectuals. Unable to articulate the larger macrosocial conditions which shpaed conflicts between numerous groups in American society and comprehend the unique differences between the U.S. and Jamaica, Garvey did not learn from his mistakes. Against such a background Garvey's cultural and symbolic political style and agenda provided a short run alternative for certain segments of the urban Black community, while ignoring other more mobile and resource capable allies and a long run focus.

\section{REFERENCES}

Aronowitz, Stanley

1979 "History As Disruption: On Benjamin and Foucault," Humani ties and Society, Vol. 2, No. 2:125-148.

Berger, Bennet $M$.

1981 (Forthcoming) Ideological Work. Berkeley: University of California Press.

Blauner, Robert

1972 Racial Oppression in America. New York: Harper and Row. Bonacich, Edna

1976 "Advanced Capitalism and Black/White Race Relations in the U.S.: A Split Labor Market Interpretation," American Sociological Review 41:34-51.

Chronon, Edmund David

1955 Black Moses. New York: Random House.

Clarke, John Henrik

1974 Marcus Garvey and the Vision of Africa. New York: Vintage Books.

Combs, David E.

1980 Dimensions of Political Drama. Santa Monica: Goodyear.

Cruse, Harold

1967 The Crisis of the Negro Intellectual: From Origins to the Present. New York: William Morrow and Company.

Davis, David Brian

1966 The Problems of Slavery in Western Culture. Ithaca, New York: Cornell University Press.

Drake, St. Claire and Horace Clayton

1932 Black Metropolis: A Study of Negro Life in a Northern City. New York: Harcourt, Brace and Co.

Dubois, W.E.B.

1913 "The Jim Crow Argument," Crisis, pp. 39-45.

Edelman, Murray

1966 The Symbolic Uses of Politics. Urbana: University of Illinois Press.

Fisher, Claude

1976 The Urban Experience. New York: Harcourt Brace Jovanovich, Inc.

Fox, Danielo et al. (eds.)

1972 Key Issues in the Afro-American Experience. New York: Harcourt Brace Jovanovich, Inc.

Franklin, John Hope

1974 From Slavery to Freedom A History of Negro Americans, 4th edition. New York: Knopf. 
Fusfeld, Darrick

1973 The Basic Economics of the Urban Racial Crisis. New York: Holt, Rinehart, and Winston.

Goffman, Irving

1959 The Presentation of Self in Everyday Life. New York: Doubleday Anchor.

Gouldner, Alvin

1976 The Dialectic of Ideology and Technology. New York: SeaGusfeld, Joseph bury Press.

1966 Symbolic Crusade. Urbana: University of Illinois Press.

Gordon, Milton

1964 Assimilation in American Life: The Role of Race, Religion, and National Origins. New York: Oxford.

1978 Human Nature, Class and Ethnicity. New York: Oxford.

Huggins, Nathan

1977 Harlem Renaissance. New York: Oxford University Press.

Kahler, E.

1970 "The Nature of The Symbol," in Rollo May (ed.), Symbolism in Religion and Literature. New York: Brauiller.

Klapp, Orin E.

1964 Symbolic Leaders: Public Drama and Public Men. New York: Minerva Press.

1978 Opening and Closing: Strategies of Information Adaptation in Society. New York: Cambridge, Massachusetts.

Klebanow, Dianna et al.

1977 Urban Legacy: The Story of American's Cities. New York: Mentor.

Kuklick, Hennka

1980 "Restructuring the Past: Toward an Appreciation of the Social Context in Science," The Sociological Quarterly 21:5-21.

\section{Lacy, Dan}

1972 The White Use of Blacks in America. New York: McGraw-Hill.

Lasch, Christopher

1974 The World Nations: Reflections on American History, Politics and Culture. New York: Vin tage Press.

1979 The Culture of Narcissism. New York: W.W. Norton.

LeVine, David

1972 Internal Combustion: The Races in Detroit - 1915-1916. New Martin, Tony York: Harper and Row.

1974 "Some Aspects of the Political Ideas of Marcus Garvey," in Henrik Clarek (ed.), The Vision of Africa. New York: Vintage Press.
Mason, Philip

1970 Race Relations. New York: Oxford.

Meier, August and Eliot Rudwick

1970 Black Protest in the Sixties. Chicago: Quadrangle.

Miller, Kelly

1974 "After Marcus Garvey - What of the Negro," in Clarke, J.H. (ed.), Marcus Garvey. New York: Vintage Books.

Moore, Richard B.

1974 The Critics and Opponents of Marcus Garvey. New York: Vintage Press.

Nelson, David Gordon

1976 Black Ethos: Northern Urban Negro Life and Thought, 1890 1930. North Carolina: Greenwood Press.

Pinkney, Alphonso

1976 Red, Black and Green: Black Nationalism in the United States. New York: Cambridge University Press.

Redkey, Edwin S.

1974 The Flowering of Black Nationalism: Henry McNeal Turner and Sindran, Ben Marcus Garvey. New York: Vintage Press.

1971 Black Talk. New York: Harper and Row.

Spear, Allan $\mathrm{H}$.

1967 Black Chicago, The Making of a Negro Ghetto. Chicago: University of Chicago Press.

Stampp, Kenneth M.

1965 The Peculiar Institution: Slavery in the Ante-Bellum South.

Tabb, William K.

1970 The Political Economy of the Black Ghetto. New York: W.W. Norton and Company.

Twombly, Robert C.

1971 Blacks in White America Since 1865: Issues and Interpretations. New York: Harper and Row.

Van Den Berghe, $P$.

1978 Race and Racism: A Comparative Perspective, 2nd edition. New York: John Wiley and Sons, Inc.

Vincent, Edward

1970 Black Power and The Garvey Movement. San Francisco: Ramparts Press.

Wilson, William J.

1973 Power, Racism, and Privilege: Race Relations in Theoretical and Sociohistorical Perspectives. New York: Macmillan.

1978 The Declining Significance of Race. Chicago: University of Chicago Press.

Yinger, J. Milton

1960 "Contraculture and Subculture," American Sociological Review 25:625-635. 